\title{
Cash and Corporate Control
}

\author{
OLUBUNMI FALEYE*
}

\begin{abstract}
The takeover market is often suggested as appropriate for containing the agency problems of excessive corporate cash holdings. However, recent studies report contradictory evidence. I focus on the takeover-deterrence effects of corporate liquidity and suggest the proxy contest as an effective alternative control mechanism. I find that proxy fight targets hold $23 \%$ more cash than comparable firms, and that the probability of a contest is significantly increasing in excess cash holdings. Proxy fight announcement return also is positively related to excess cash. Following a contest, executive turnover and special cash distributions to shareholders increase, while cash holdings significantly decline.
\end{abstract}

QUITE OFTEN, THE TAKEOVER MARKET is suggested as ideal for containing the agency problems of corporate free cash flow. Contrary to this, however, Harford (1999) and Pinkowitz (2002) both find that the likelihood of a firm becoming a takeover target is significantly negatively related to the holding of excess cash. This result could be explained in terms of the takeover-deterrence effects of corporate liquidity. Excess cash enhances the ability of a hostile target to defend itself against an unwanted bid. Such defenses include repurchasing stock, acquiring a competitor of the bidder and filing private antitrust litigation, or turning around to acquire the suitor itself (Bagwell (1991), Stulz (1988), and Dann and DeAngelo (1988)). In addition, excess cash increases the bidder's uncertainty about the value of the target since it can be used to engage in bidder-specific negative net present value activities. Thus, holding excess cash may serve as a deterrent to would-be bidders.

This paper focuses on the takeover-deterrence effects of excess cash and suggests the proxy contest as an effective control mechanism for addressing the agency problems of excessive corporate liquidity. As in a hostile takeover situation, management will employ all available defenses in a proxy contest. Nevertheless, I propose that dissident shareholders conducting a proxy fight independently of a takeover bid are not encumbered by the considerations that may deter a hostile bidder.

* Olubunmi Faleye is from the College of Business Administration, Northeastern University. With many thanks, I acknowledge comments from Paul Bolster, David Denis, Rick Green (the editor), Vikas Mehrotra, Randall Morck, and seminar participants at the University of Alberta, University of Lethbridge, St. Mary's University, Northeastern University, University of Wisconsin-Milwaukee, and annual meetings of the Northern Finance Association, European Finance Association, and Financial Management Association. I am especially grateful to Mark Huson and an anonymous referee for their numerous comments and suggestions, which have significantly improved the paper. Any remaining errors are my sole responsibility. 
I investigate my hypothesis using a sample of 98 proxy contests conducted without an accompanying takeover bid between 1988 and 2000. I find that target firms hold $23 \%$ more cash than similar non-targets, and that the probability of a proxy contest is significantly positively related to excess cash holdings: A movement from the first to the third quartile of excess cash increases the odds in favor of a proxy contest by $39.27 \%$. This finding is not sensitive to the manner in which excess cash is measured or to alternative specifications of the control group. I also find that the abnormal return accompanying a proxy fight announcement is significantly positively related to excess cash holdings, suggesting that investors anticipate more efficient cash management following a proxy fight. Post-contest operating changes suggest that investors' expectations are realized. Following a contest, executive turnover and special cash distribution to shareholders increase, while excess cash holdings significantly decline.

This paper enhances our understanding of the effectiveness of external control in containing the excess liquidity problem and the specific manner in which excess cash is disgorged. In addition, it provides systematic evidence on the role of specific agency issues in influencing the occurrence of a proxy fight. When dissidents wage a proxy contest, they are not just concerned about the overall picture (as reflected in, say, stock performance or earnings), but also about particular issues relating to management's control of the firm. Finally, it provides additional evidence on the efficiency of the corporation as an economic institution. Although management is largely free to act without interference from shareholders and is able to employ various devices to protect its interests, the extent to which it can engage in non-value-enhancing activities is limited by control mechanisms such as the proxy contest.

The remainder of the paper is organized as follows. In the next section, I review the literature on the agency issues arising from excess liquidity, the corporate control implications of these issues, and my motivation for this study. I describe my measure of excess liquidity in Section II, while sample selection procedures and the resulting sample are discussed in Section III. Section IV contains empirical analysis, and Section V concludes.

\section{Excess Liquidity as an Agency Problem}

Jensen (1986) lays out the agency issues raised by excess liquidity and defines free cash flow as cash flow in excess of what is needed to finance all positive net present value projects. By definition, such cash flow should be paid out to the firm's shareholders since the corporation cannot invest it profitably on their behalf. However, paying out excess cash reduces the resources under management's control, restricts management's ability to pursue corporate growth, and increases the probability of raising funds externally to finance future projects. Management would rather avoid these things. Thus, self-interested utility maximizing managers would prefer to retain excess liquidity.

Jensen and Meckling (1976) suggest that management could engage in bonding activities that eliminate or reduce the potential for agency conflicts. In the 
context of the excess liquidity problem, such activities include substituting debt and other fixed claims for common equity (Masulis (1980), Copeland and Lee (1991)), increasing payout to shareholders through a stock repurchase or special dividends (Vermaelen (1981), Nohel and Tarhan (1998)), or taking the firm private in a leveraged buyout (Lehn and Poulsen (1989), Opler and Titman (1993)). The abnormal returns accompanying these transactions suggest that investors recognize the potential for agency problems in the utilization of cash and reward firms whose managers take suitable actions to minimize such problems. Yet, Jensen (1993) shows that management is often reluctant to make appropriate changes. In such instances as this, where the internal control system fails to address agency-related issues, investors rely on external control mechanisms to redirect management toward optimal behavior or otherwise replace the incumbent team.

A commonly suggested mechanism is the takeover market. Jensen (1986, p. 328) argues that the free cash flow theory "predicts value increasing takeovers occur in response to breakdowns of internal control processes in firms with substantial free cash flow." Similarly, Pinkowitz (2002, pp. 5-6) highlights several quotes from industry publications suggesting that the takeover market should discipline cash-rich firms. However, recent evidence suggests that this is not the case.

Pinkowitz (2002) examines the role of the takeover market in monitoring firms with excess cash and finds that the probability of receiving a hostile bid is negatively related to the holding of excess cash. On average, firms that were not targeted hold about $40 \%$ more cash than those that were, and a firm moving from the first to the third quartile of cash holdings decreases the probability of a bid by about 18\%. Harford (1999) performs a similar analysis with similar results.

There are several reasons why the market for corporate control might fail with respect to firms with free cash. Excess cash provides a corporation with many anti-takeover defense options that may otherwise be unavailable. One such option is to repurchase stock, which reduces the possibility of a successful acquisition in several ways. Harris and Raviv (1988) and Stulz (1988) both argue that a stock repurchase could be used to disproportionately concentrate voting power in management's and other friendly hands by buying stock from nonaffiliated shareholders. In addition, a stock repurchase could significantly increase the cost to a hostile bidder. Bagwell (1991) shows that in the presence of heterogeneous investor valuations, a share repurchase increases the cost of a takeover by altering the marginal shareholder. Bagwell (1992) provides empirical evidence indicating that firms face upward-sloping supply curves when they repurchase shares in a Dutch auction.

Prior empirical work supports the deterrence effects of the stock repurchase. Dann and DeAngelo (1988) find that the bidder failed to acquire control of the target in all eight cases in which the target repurchased shares as part of its defensive maneuvers. Similarly, Denis (1990) reports that only 7 out of 26 firms that implemented a stock buyback in response to a hostile bid were eventually acquired. In fact, the stock repurchase is so closely associated with 
anti-takeover motives that firms implementing one for different reasons often explicitly mention this in their public statements (Bagwell (1991)). While it is possible for any firm to undertake a repurchase by borrowing funds, it is clear that a cash-rich target is more able to defend itself in this manner, since it does not have to worry about the readiness of the capital markets to provide funds.

Dann and DeAngelo (1988) show that the target of a hostile bid could also defend itself by acquiring a competitor of the bidder. This has the potential to deter a bidder since the target could then file a private antitrust litigation claiming that allowing the bidder to acquire it would hurt consumers by eliminating or reducing competition. Alternatively, a cash-rich target could make a reverse bid for an unwanted suitor. If managers attach a nontrivial probability to the success of such a bid, this possibility may serve as a deterrent against making a hostile bid for a cash-rich target.

In view of the many ways in which a target's excess liquidity could be used to frustrate an acquisition attempt, it is not surprising that Harford (1999) and Pinkowitz (2002) find cash holdings to be a deterrent for takeover bids. This leaves open the question of which control mechanisms discipline this class of firms. Pinkowitz (p. 8) concludes that "if the market for corporate control cannot prevent managers from holding cash, there may be no device (short of ex ante contracting) which serves as a check on corporate cash holdings." However, we do not observe such ex ante contracting in practice.

This paper suggests the proxy contest as an effective alternative for addressing the agency problems of excess cash. By definition, a proxy fight is a hostile control activity. This implies that management will deploy all available defenses when faced with one. In spite of this, there are several reasons why we might expect excess cash firms to be targeted in proxy contests. These reasons revolve around the fact that the extra defenses a cash-rich firm may employ against a hostile bidder are largely ineffective against dissident shareholders waging a proxy fight. In this regard, it is important to distinguish between a plain proxy fight and one conducted jointly with a takeover bid. Apart from being inherently more expensive, a joint takeover bid/proxy fight makes dissidents susceptible to the anti-takeover defenses at management's disposal. For example, the tactic of repurchasing stock is shown to be a strong deterrence for unwanted acquisition bids. However, it cannot discourage a plain proxy contest intended to force management to disgorge excess cash. This is because dissident shareholders in this case would be satisfied to see management repurchase stock in response to a proxy fight. ${ }^{1}$ Indeed, dissidents often demand a stock repurchase when

\footnotetext{
${ }^{1}$ A stock repurchase undertaken in response to a takeover threat (with or without a proxy fight) also accomplishes the purpose of disgorging excess cash. However, management would only repurchase if it considers the threat credible, for instance, if the bidder has secured financing and/or made an offer to the target's shareholders. From the dissidents' point of view, it is more difficult and expensive to make a credible takeover threat than it is to threaten a proxy fight. Thus, dissidents would prefer a proxy fight. I am grateful to David Denis for raising this point.
} 
their main complaint against incumbent management is excessive corporate liquidity. $^{2}$

Similarly, the threat of antitrust litigation or a reverse bid cannot discourage dissidents from seeking control via a proxy fight unless they are also interested in actually acquiring the firm. The fact that plain proxy contests often are initiated by individuals or institutional investors makes these threats particularly meaningless. Thus, we would expect firms with excess liquidity to be targeted in proxy contests. Such contests should, however, occur independently of a takeover bid. ${ }^{3}$

\section{A. Other Control Variables}

Since a proxy fight is a contest for control between incumbent management and a dissident shareholder group, several factors apart from excess liquidity could play significant roles in determining whether a firm becomes a target in such a contest. One such factor is managerial ownership. The probability of a dissident group attaining seats on a company's board is decreasing in the proportion of shares controlled by management. Indeed, if management controls $50 \%$ or more of the firm's voting power and directors are not elected through cumulative voting, dissidents are guaranteed to fail and no proxy contests would occur. Besides, higher managerial ownership reduces the likelihood of severe agency problems that may be addressed via a proxy fight. Thus, firms with high managerial ownership should be less likely to become targets in proxy contests.

A proxy solicitation involves substantial expenditures in communicating with and persuading shareholders. If ownership is concentrated in a few hands, this would reduce the cost of communicating with shareholders and make a proxy contest more affordable and less time-consuming. Note that this reduction in cost is of less value to management, since management uses the corporation's resources to defend itself. Hence, it is plausible that proxy contests would be more probable in firms with nonaffiliated blockholders. Consistent with this, Pound (1988) shows that the success of a proxy contest is significantly related to institutional stockholdings.

\footnotetext{
${ }^{2}$ Examples of contests in which dissidents explicitly demanded a stock repurchase include Tiger Management Group vs. Cleveland-Cliffs, 1991; Dickstein Partners vs. Hills Stores, 1994; and Relational Investors vs. Storage Technology, 1997.

${ }^{3}$ Anecdotal evidence suggests that the choice environment is more often one in which a bidder chooses between a stand-alone takeover bid and a takeover bid combined with a proxy contest than one in which a dissatisfied shareholder chooses between a proxy contest and a proxy contest with takeover bid. In all cases in my sample where the same entity launched a takeover bid combined with a proxy fight, the takeover bid came first. The proxy contest was subsequently launched in response to management's opposition to the bid. Previous versions of the paper show that the occurrence of a joint takeover bid/proxy fight is unrelated to excess cash holdings and that targets of such contests do not increase cash distributions after the proxy fight. Even when they do make cash distributions, those distributions are often intended to frustrate the hostile bid. These results are available from the author upon request.
} 
Poor corporate performance makes management visible as not maximizing shareholder wealth. In addition, shareholders will be less inclined to vote against incumbent management if the firm's performance is at least as good as that of its peers. Thus, the likelihood of a proxy contest should be decreasing in the firm's performance (DeAngelo (1988)).

\section{Variable Definitions}

\section{A. Excess Cash}

An important consideration in studies of the free cash flow hypothesis is the measurement of excess cash. Several proxies are proposed in the literature, including cash and marketable securities normalized by total assets or sales and undistributed post-tax cash flow. The problem with these proxies is that they do not account for cross-sectional differences in investment and other operational needs. The usual way of correcting for this is to include a proxy for investment opportunities in the model testing the effect of free cash flow. A better approach would be to explicitly model the cash process. Opler et al. (1999), hereafter OPSW, provide such a model.

In the OPSW model, cash holding is a function of growth opportunities, riskiness of cash flow, access to the capital markets, and the cost of raising funds through asset sales and dividend cuts. For firm $i$ in year $t$, the cash model is given by the following equation:

$$
\begin{aligned}
\text {CASH }_{i, t}= & a+b_{1} \text { MTB }_{i, t}+b_{2} \text { SIZE }_{i, t}+b_{3} \text { CF }_{i, t}+b_{4} \text { NWC }_{i, t}+b_{5} \text { CAPEX }_{i, t} \\
& +b_{6} \operatorname{LEVERAGE}_{i, t}+b_{7} \operatorname{INDSIG}_{i, t}+b_{8} \text { FINDIS }_{i, t} \\
& +b_{9} \operatorname{DIVDUM}_{i, t}+b_{10} \operatorname{REGDUM}_{i, t}+\epsilon_{t} .
\end{aligned}
$$

In the above equation, $C A S H$ is the natural log of the ratio of cash and marketable securities to assets less cash or net assets; $M T B$ is market/book ratio; $S I Z E$ is the natural log of assets in 1994 dollars; $C F$ is the ratio of cash flow to net assets; $N W C$ is the ratio of net working capital (net of cash) to net assets; $C A P E X$ is the ratio of capital expenditures to net assets; LEVERAGE is total debt over total assets; INDSIG is the mean of standard deviations of cash flow over assets over 20 years for firms in the same industry as defined by two-digit SIC code; FINDIS is the ratio of R\&D expenditures to sales; DIVDUM is a binary variable set to one if the firm paid a dividend in the year, and zero if it did not; and REGDUM is a dummy variable that equals one if the firm is in a regulated industry for the year and zero if it is not.

I measure excess cash as the difference between actual cash holdings and cash holdings predicted by the OPSW model estimated cross-sectionally each year over all COMPUSTAT firms during my sample period. Annual cross-sectional estimation permits model coefficients to change from year to year, thereby allowing the determinants of cash holdings to vary over time. ${ }^{4}$

\footnotetext{
${ }^{4} \mathrm{I}$ am grateful to the referee for pointing this out.
} 


\section{B. Equity Ownership}

I define two equity ownership variables: managerial ownership and outside block ownership. Managerial ownership is the proportion of outstanding shares controlled by management, either directly or indirectly, as reported in the proxy filing immediately before the proxy contest. Outside block ownership is the percentage of outstanding shares owned by nonaffiliated shareholders (excluding the dissident group) holding at least $5 \%$ of total shares as reported in the proxy statement immediately preceding the contest.

\section{Pre-contest Performance}

I measure pre-contest performance using market-adjusted stock return. This is calculated as the 1-year buy-and-hold return from 15 to 3 months before the proxy contest announcement date less the same-period return on CRSP value-weighted portfolio of NYSE, AMEX, and Nasdaq stocks. DeAngelo (1988) shows that for a sample of 86 proxy contests conducted between 1970 and 1983, dissident shareholders usually cite poor earnings rather than stock price performance and that target companies' pre-contest earnings are significantly below the market. Perhaps due to a shift in investor sophistication arising from differences in sample period, stock price issues constitute a more frequent performance complaint than earnings in my sample. For this reason, I employ the measure defined above. As a robustness check, I repeat all analysis using earnings rather than stock return as the measure of performance. Results are similar to those obtained with stock return and are therefore not reported.

\section{Sampling and Data}

I search the Wall Street Journal Index from 1988 to 2000 for proxy contest information, which yields 274 contests involving non-financial firms. I exclude financial firms because their cash holdings may be subject to extraneous influences, such as government regulation. Of the 274 contests, 127 do not have proxy filings or enough data to allow computation of excess cash. Excluding these firms reduces the sample to 147 contests. I also exclude 49 firms that were targets of a takeover bid in the 1-year period centered on the proxy fight. Thus, the final sample consists of 98 contests.

The most common criticism of incumbent management is poor corporate performance, cited in $53.06 \%$ of all cases. In $25 \%$ of contests, dissidents seek one form of corporate restructuring or the other. Such restructuring includes divestiture of noncore business divisions, breakups, and leverage reduction. Outright sale of the business is sought in $21.43 \%$ of the contests. Cash-related issues are raised in $14.29 \%$ of the cases, with dissidents seeking stock repurchases, dividend increases, and/or to block undesirable acquisitions.

In order to reduce the cost of hand-collecting data from proxy statements, I utilize case-control matching for my empirical analysis. However, a strict 
matching results in a significant loss of sample firms because of the data requirement for the cash model and the need for control firms to have proxy filings. To mitigate this, I select as control firms the four firms in the same fourdigit SIC group nearest to the contest firm in total assets in the year before the proxy contest. If enough control firms cannot be found in the four-digit SIC, I select three-digit SIC firms. I do not require that these firms be within any particular percentage point of the contest firm's assets. The resulting control sample does not differ significantly from the contest firms on asset base. Nevertheless, I estimate additional regressions utilizing different specifications of the control sample to address possible economic differences across the two samples. These regressions and other robustness checks are discussed further in Section IV.

Table I presents descriptive statistics for contest and control firms. For contest firms, mean and median assets in 1994 dollars are $\$ 2.89$ billion and $\$ 249$ million, respectively. Corresponding figures for the control group are $\$ 1.73$ billion and $\$ 195$ million. Neither is significantly different from the value for the contest firms. Mean and median cash-to-assets ratio for contest firms are $12.82 \%$ and $8.56 \%$, respectively, compared to $10.39 \%$ and $5.79 \%$ for control firms. The differences are statistically significant at the $1 \%$ level for the median and $10 \%$ level for the mean, suggesting that target firms are more liquid than nontargets. The same pattern obtains in the distribution of excess

\section{Table I}

\section{Descriptive Statistics}

The variable Assets is total assets in 1994 dollars; Cash-to-assets is the ratio of cash and marketable securities to total assets; Excess cash is the prediction error of Opler et al.'s (1999) cash model; Managerial ownership is the proportion of outstanding voting shares controlled directly or indirectly by management; and Outside block ownership is the percentage of outstanding shares owned by nonaffiliated shareholders of at least $5 \%$ of outstanding shares. Outside block ownership excludes the dissidents' holding. Stock return is the 1-year buy-and-hold return estimated from 15 to 3 months prior to the proxy contest announcement date. The variable Net-of-market return is unadjusted return less same-period return on CRSP value-weighted portfolio of NYSE, AMEX, and Nasdaq stocks. The sample covers 1988-2000 and consists of 439 firms of which 98 are targets of a proxy fight and the rest are non-targets. For each variable, $* * *$ and $*$ indicate that the value for contest firms is significantly different from the value for control firms at the $1 \%$ and $10 \%$ levels, respectively.

\begin{tabular}{|c|c|c|c|c|}
\hline \multirow[b]{2}{*}{ Variable } & \multicolumn{2}{|c|}{ Control Firms } & \multicolumn{2}{|c|}{ Contest Firms } \\
\hline & Mean & Median & Mean & Median \\
\hline Assets (\$ million) & 1,728 & 195 & 2,893 & 249 \\
\hline Cash-to-assets & $10.39 \%$ & $5.79 \%$ & $12.82 \% *$ & $8.56 \% \%^{* * *}$ \\
\hline Excess cash & 0.0423 & 0.0033 & $0.0722^{* * *}$ & $0.0367^{* * *}$ \\
\hline Market/book ratio & 1.709 & 1.303 & 1.482 & $1.129^{* * *}$ \\
\hline Managerial ownership & 0.253 & 0.197 & $0.102^{* * *}$ & $0.063^{* * *}$ \\
\hline Outside block ownership & 0.085 & 0.053 & $0.140^{* * *}$ & $0.105^{* * *}$ \\
\hline Net-of-market return & -0.010 & -0.050 & $-0.168^{* * *}$ & $-0.252^{* * *}$ \\
\hline Sample size & \multicolumn{2}{|c|}{341} & \multicolumn{2}{|c|}{98} \\
\hline
\end{tabular}


cash. Mean and median excess cash for control firms are 0.0423 and 0.0033 , respectively. Neither is significantly different from zero, and both are comparable to numbers reported in other studies employing the OPSW model (see Pinkowitz (2002) and Pinkowitz and Williamson (2001), for example). In contrast, mean and median excess cash for contest firms are both significant at the $1 \%$ level. For these firms, average excess cash is 0.0722 , while the median is 0.0367 . Each is significantly higher than the corresponding value for control firms at the $1 \%$ level.

Table I also shows that contest firms have lower managerial ownership, higher outside block ownership, and have significantly underperformed the market in terms of stock return. In addition, the market/book ratio is lower for contest firms, although the difference is only significant in the median. This raises the concern that results may be driven by investment opportunities, since firms with fewer investment options should hold less cash and thus might have more excess cash. Hence, the fact that contest firms have significantly more excess cash may simply be a market/book effect. Note, however, that the excess cash calculations control explicitly for market/book. In addition, results of tests conducted with raw cash/assets are virtually identical to those performed with excess cash. Thus, it is unlikely that the results are driven by investment opportunities.

\section{Empirical Analysis, Results, and Discussion}

\section{A. Excess Cash and the Probability of a Proxy Fight}

I begin my analysis by estimating logistic regressions relating the probability of a proxy contest to excess cash holdings and the control variables described in Section I.A. In each regression, the dependent variable is a binary variable that equals one for targets and zero for non-targets. Since the control group consists of size- and industry-matched firms, I estimate all regressions using conditional logits. Each regression also includes year dummies as additional explanatory variables, although the coefficients are not reported. Results are presented in Table II.

Model I in Table II is the base regression. Excess cash in this model is estimated from the OPSW model. As shown in the table, the results indicate that the probability of a proxy fight is significantly positively related to excess cash holdings. The model has a hazard ratio of 1.027 , which implies that a movement from the first to the third quartile of excess cash increases the odds in favor of a proxy fight by $39.27 \%$. The regression results also show that the likelihood of a proxy contest is significantly decreasing in managerial ownership and marginally increasing in outside block ownership.

These results suggest that cash-rich firms are significantly more likely to become targets of a stand-alone proxy fight. As corroborating evidence, I examine how long contest firms have excess cash before they are targeted. I compute annual excess cash decile ranks for all firms in COMPUSTAT from 4 years before the first event year in my sample to 1 year before the last event 


\section{Table II}

\section{Excess Cash and the Probability of a Proxy Contest}

In Model I, Excess cash is the prediction error of Opler et al.'s (1999) cash model. In Model II, Excess cash is the prediction error of Harford's (1999) cash model. The variable Cash ratio in Model III is the natural logarithm of cash/assets; Managerial ownership is the proportion of outstanding voting shares controlled directly or indirectly by management; and Outside block ownership is the percentage of outstanding shares owned by nonaffiliated shareholders of at least $5 \%$ of outstanding shares. Outside block ownership excludes the dissidents' holding. Unadjusted stock return is the 1-year return estimated from 15 to 3 months prior to the proxy contest announcement date. The variable Market-adjusted return is unadjusted return less the same-period return on CRSP value-weighted portfolio of NYSE, AMEX, and Nasdaq stocks. The variable Debt ratio is total debt divided by total assets. Each model includes year dummies. In each regression, the dependent variable is a dummy variable, which equals zero for non-targets and one for targets. Since the non-target group consists of size- and industry-matched firms, the regressions are estimated using conditional logit. The $p$-value for $\chi^{2}$-test of parameter significance is shown in parentheses under each parameter estimate. The sample covers 1988-2000.

\begin{tabular}{lccc}
\hline Variable & Model I & Model II & Model III \\
\hline Excess cash & 2.6367 & 3.4585 & - \\
& $(0.05)$ & $(0.04)$ & 0.2953 \\
Cash ratio & - & - & $(0.02)$ \\
Managerial ownership & -6.6129 & -3.4224 & -6.7701 \\
& $(0.01)$ & $(0.06)$ & $(0.01)$ \\
Outside block ownership & 1.8209 & 1.5686 & 1.7310 \\
& $(0.07)$ & $(0.33)$ & $(0.09)$ \\
Market-adjusted return & -0.4519 & -0.3941 & -0.3222 \\
& $(0.14)$ & $(0.47)$ & $(0.23)$ \\
Market/book ratio & - & - & -0.0651 \\
& & & $(0.58)$ \\
Debt ratio & - & - & 2.9923 \\
Likelihood ratio test $(p$-value) & 68.61 & 17.11 & $(0.01)$ \\
& $(0.01)$ & $(0.02)$ & 81.03 \\
Sample size & 439 & 439 & $(0.01)$ \\
\end{tabular}

year, that is, from 1984 to 1999. I then examine decile ranks for targets in the 4 years preceding their proxy fights. I classify each year as either an excess cash year or not, with an excess cash year being one in which the contest firm is in the upper $40 \%$ of the distribution of excess cash. I find that on average, contest firms have excess cash for a period of 2 years before becoming a target. These years are generally those immediately before the proxy contest. ${ }^{5}$

\footnotetext{
${ }^{5}$ I also estimate a proportional hazards model over all COMPUSTAT firms in which the dependent variable is proxy fight survival time during 1987 to 2000 and the explanatory variable is excess cash. For targets of a proxy fight, survival time is the number of years after 1987 before they become targets. For nontargets, survival time is treated as censored at 13 years (i.e., the difference between 2000 and 1987). Consistent with the matched-sample results, the regression indicates that the probability of a contest is significantly positively related to excess cash holdings.
} 


\section{B. Sensitivity and Robustness Check}

The above results suggest that excessive corporate liquidity plays an important role in the proxy contest process. However, it is possible that these results are dependent on the measure of excess cash. Thus, it is important to examine the sensitivity of results to changes in this measure.

As a starting point, I estimate conditional logit regressions in which excess cash is based on an alternative model of cash holdings proposed by Harford (1999). In Harford's model, corporate cash holding is a function of firm size, investment opportunities, cash flow volatility, future cash flows, industry characteristics, and general economic conditions. I estimate Harford's model crosssectionally each year, with two slight modifications. First, because the regressions are cross-sectional, I do not include the firm-specific fixed effects employed in Harford's original estimation. Second, Harford controls for industry effects by estimating a separate regression for 19 broadly defined industry groups. Since I do not have the data on his industry classification, I utilize one-digit SIC industry dummies to control for industry effects. The results obtained using this model are comparable to those reported earlier and are shown under Model II in Table II.

As a further robustness check, I estimate conditional logit regressions relating the probability of a proxy contest to cash holdings (as measured by the ratio of cash and marketable securities to total assets) and the standard control variables. I include market/book ratio as an additional explanatory variable to control for cross-sectional differences in investment opportunities. Smith and Watts (1992), Opler et al. (1999), and Harford (1999) are among prior studies that employ the market/book ratio as a proxy for investment opportunities. Likewise, I include leverage ratio (total debt to total assets) to control for differences in debt usage and thus ensure that my findings reflect the effect of net cash holdings. Results are very similar to those obtained with the OPSW model and are presented under Model III in Table II.

In addition, I examine the sensitivity of results to changes in the specification of control firms by estimating regressions using different subsets of the control sample. While the difference in asset base between contest and control firms is statistically insignificant, it is possible that there are economic differences in firm size that may affect the results. The first set of regressions uses control firms whose assets are within $30 \%$ of the total assets of the corresponding contest firm in the year before the proxy fight. The second set of regressions uses control firms that are smaller, while the third uses control firms that are larger than the respective contest firm. In spite of the differences in firms that make up the control samples in these regressions, I obtain the same pattern of coefficients and significance as in Table II. Thus, the findings do not appear to depend on the specification of the control sample.

\section{Excess Cash and Proxy Contest Announcement Return}

The preceding section documents a significant association between excessive corporate liquidity and the occurrence of a proxy fight. In this section, I consider 
the effectiveness of the proxy contest in reducing financial slack by examining the relation between excess cash holdings and the abnormal return accompanying a proxy fight announcement. In an efficient market, if the proxy fight is effective in alleviating the agency problems of excess cash, then proxy contest announcement returns should be positively related to excess cash holdings. I define the announcement date as the earliest date of initial dissident activity as reported in the Wall Street Journal, Dow Jones News Service, PR Newswire, or Business Newswire.

Following a standard event study methodology, I estimate the market model for each contest firm over the period from 250 to 21 days prior to the announcement date and then use estimated parameters to calculate abnormal returns around contest initiation. One firm does not have sufficient data in CRSP to allow computation of abnormal returns and is not included in the following analysis. Announcement period abnormal return is defined as the three-day cumulative abnormal return (CAR) calculated over days $(-1,+1)$ relative to the announcement date. Consistent with prior studies, average CAR is positive and significant. Mean and median CAR are $5.18 \%$ and $1.78 \%$, respectively. Both are significant at less than the $1 \%$ level.

I estimate a regression of CAR on excess cash to test whether investors anticipate more efficient cash management following a proxy contest. The results are consistent with this hypothesis. The coefficient of excess cash is 0.017 , which is significant with a $p$-value of 0.04 . The regression has an adjusted $R^{2}$ of 0.06 . In terms of economic significance, a movement from the first to the third quartile of excess cash more than doubles the cumulative abnormal return, from $2.51 \%$ to $5.19 \%$. Thus, the finding strongly suggests that investors expect firms to make wealth-increasing changes in their cash management policies after a proxy contest.

\section{Post-contest Liquidity and Operating Changes}

An important question that remains is "How does the proxy fight lead to more efficient cash management?" First, it is important to know whether target firms continue to hold abnormally high levels of cash following a proxy contest. I find that average cash ratio falls from $12.82 \%$ pre-contest to $9.15 \%$ in the year after the contest. The reduction is statistically significant at the 5\% level. More importantly, average excess cash goes down from 0.0722 pre-contest to 0.0351 in the post-contest year. The decrease in excess cash is statistically significant at the $1 \%$ level. Thus, the occurrence of a proxy fight in these firms is followed by a significant reduction in excess liquidity.

Notwithstanding the above, however, further tests are required before it could be inferred that the reduction in excess cash experienced by the contest firms is related to the occurrence of a proxy fight. I accomplish this by grouping all COMPUSTAT firms into annual excess cash quartiles over my sample period. I then use the quartile ranks to estimate conditional and unconditional excess cash transition probabilities. The conditional transition probability is the empirical probability of a firm moving from one excess cash quartile during year 


\section{Table III}

\section{Conditional and Unconditional Empirical Excess Cash Transition Probabilities, 1988-2000}

The transition probability for cell $(i, j)$ is the probability of a firm moving from excess cash quartile $i$ during year $t-1$ to excess cash quartile $j$ in year $t+1$. The first entry (bold typeface) in each cell is the transition probability conditioned on the firm being the target of a proxy contest in year $t$. The second entry is the unconditional transition probability estimated over all COMPUSTAT firms not involved in a proxy fight during the period 1988-2000. For example, entries in the last row reflect the probabilities of a firm moving from the fourth quartile of excess cash in year $t-1$ to various quartiles in year $t+1$, so that such a firm targeted in a proxy fight during year $t$ remains a fourth quartile firm with probability 0.361 , while a similar fourth quartile firm not targeted in a proxy fight remains a fourth quartile firm with probability 0.568 . The probabilities do not sum up to one because of rounding errors. Numbers in parentheses are actual cell frequencies for proxy fight targets. The last column gives the distribution of target firms into different excess cash quartiles in the year immediately preceding the proxy fights.

\begin{tabular}{|c|c|c|c|c|c|}
\hline $\begin{array}{l}\text { Post/ } \\
\text { Pre }\end{array}$ & $\begin{array}{c}\text { First } \\
\text { Quartile }\end{array}$ & $\begin{array}{c}\text { Second } \\
\text { Quartile }\end{array}$ & $\begin{array}{c}\text { Third } \\
\text { Quartile }\end{array}$ & $\begin{array}{c}\text { Fourth } \\
\text { Quartile }\end{array}$ & $\begin{array}{c}\text { Row } \\
\text { Frequency }\end{array}$ \\
\hline \multirow[t]{2}{*}{ First quartile } & $0.417(5)$ & $0.583(7)$ & $0.000(0)$ & $0.000(0)$ & \multirow[t]{2}{*}{12} \\
\hline & 0.598 & 0.248 & 0.108 & 0.046 & \\
\hline \multirow[t]{2}{*}{ Second quartile } & $0.211(4)$ & $0.421(8)$ & $0.211(4)$ & $0.158(3)$ & \multirow[t]{2}{*}{19} \\
\hline & 0.271 & 0.420 & 0.229 & 0.081 & \\
\hline \multirow[t]{2}{*}{ Third quartile } & $0.129(4)$ & $0.387(12)$ & $0.387(12)$ & $0.097(3)$ & \multirow[t]{2}{*}{31} \\
\hline & 0.119 & 0.269 & 0.409 & 0.203 & \\
\hline \multirow{2}{*}{ Fourth quartile } & $0.028(1)$ & $0.417(15)$ & $0.194(7)$ & $0.361(13)$ & \multirow[t]{2}{*}{36} \\
\hline & 0.053 & 0.104 & 0.275 & 0.568 & \\
\hline
\end{tabular}

$t-1$ to another quartile in year $t+1$, given that the firm was the target of a proxy contest in year $t$. Unconditional transition probabilities are calculated for firms not involved in a proxy fight and represent the probability of a firm moving from one excess cash quartile in year $t-1$ to another in year $t+1$, given that the firm was not the target of a proxy fight in year $t$.

The two sets of transition probabilities are shown in Table III. The first entry in each cell (in bold typeface) is the transition probability conditioned on the occurrence of a proxy contest. Estimated unconditional transition probabilities are shown under the corresponding conditional probabilities. Now consider firms in the fourth quartile of excess cash in year $t-1$, that is, entries in the last row of Table III. The empirical probability that such a firm targeted in a proxy contest in year $t$ will remain a fourth quartile firm in year $t+1$ is 0.361 , compared to a probability of 0.568 for a fourth quartile firm not involved in a proxy fight. Not only this, a fourth quartile target remains in the upper half of the distribution of excess cash in the year after the contest with probability 0.555. The corresponding probability for a fourth quartile non-target is 0.843 . Similarly, the probability that post-contest excess cash for a third quartile target will be above the median of the distribution is 0.484 , while the corresponding figure for a non-target third quartile firm is 0.612 . Thus, the evidence suggests a relation between the reduction in excess liquidity and the occurrence of a proxy fight. 
I examine the strength of this relation by performing a $\chi^{2}$ goodness-of-fit test using frequencies generated from the probabilities in Table III. To calculate the expected frequency for a cell, I multiply the unconditional probability for that cell by the row frequency corresponding to the cell. Observed frequencies are the actual frequencies observed for the contest firms as reported in Table III. The $\chi^{2}$-test statistic is 50.85 with 9 degrees of freedom, which is significant at less than the $1 \%$ level. This indicates that the transition probabilities are significantly related to the occurrence of a proxy contest, and thus suggests that the reduction in cash holdings for contest firms is related to the occurrence of a proxy fight.

However, it is possible that cash decreases post-contest because management simply wastes it, for example, in fighting off dissidents. I investigate this by examining changes in the operations and top management of the sample firms in the year before and the year after the proxy contest. I search the Wall Street Journal Index, Dow Jones News Service, and PR Newswire for news about each contest firm in the 12 months preceding the proxy contest announcement date and the 12 months after resolution of the proxy fight. Each news item is classified into one of three categories, reflecting my judgment of its effect on the disposition of liquid resources and the identity of senior management. Results are summarized in Table IV.

Table IV shows an increase in the proportion of firms making a special cash distribution in the post-contest year. A special cash distribution is a stock repurchase (excluding targeted repurchases) or a one-time special dividend payment. In the year preceding the proxy fight, $12.24 \%$ of the sample firms made a special cash distribution compared to $19.39 \%$ in the post-contest year. However, the likelihood ratio $\chi^{2}$-test indicates that the increase is not statistically significant at conventional levels.

I also examine the amount distributed to shareholders in the form of stock repurchases and special dividends. Following Stephens and Weisbach (1998), I estimate actual repurchases based on changes in daily outstanding shares as reported in CRSP, changes in treasury stock value in COMPUSTAT, and newswire reports on completed repurchases. As reported in Table IV, average dollar distribution in the pre-contest year is $\$ 5.90$ million. This increases to $\$ 55.40$ million following the proxy fight. The difference is statistically significant at the $5 \%$ level. Furthermore, special cash distributions in the pre-contest year amount to $0.24 \%$ of total assets. By contrast, cash distributions in the year after the contest represent $1.75 \%$ of pre-contest assets. The difference is statistically significant at the $1 \%$ level. Table IV also shows a significant reduction in cash/assets and excess cash holdings, thus suggesting that the increased payout was not financed by newly raised funds. In sum, the evidence is consistent with the notion that the payout represents a distribution of excess liquidity to shareholders.

Table IV also provides summary statistics on market/book ratios and capital expenditures pre- and post-contest. If investors are concerned about excessive liquidity, then market/book ratios should be higher in the post-contest period when target firms reduce their cash holdings. The evidence in Table IV 


\section{Table IV \\ Operational Changes in the 12 Months Preceding a Proxy Contest Announcement and the 12 Months Following Resolution of the Proxy Fight}

Special cash distributions include all forms of stock repurchases (excluding targeted repurchases) and one-time special dividends announced and completed during the period. Capital expenditure is the ratio of capital expenditure to net assets. Excess cash is the prediction error of Opler et al.'s (1999) cash model. Executive turnover includes all resignations or terminations of any of the chairman of the board, the chief executive officer, or the president/chief operating officer, but excludes unforced turnovers such as retirement at normal age. Figures for executive turnover and special cash distributions are based on summaries of news items reported in the Wall Street Journal, Dow Jones News Service, Dow Jones Business News, PR Newswire, and Business Newswire. Figures for market/book ratio and capital expenditure are from COMPUSTAT. All figures apart from proportions are arithmetic averages. The sample covers 1988-2000.

\begin{tabular}{|c|c|c|c|c|}
\hline & Pre-contest & Post-contest & Change & $\begin{array}{c}\text { Test Statistic } \\
\quad(p \text {-value })\end{array}$ \\
\hline Making special cash distributions (\%) & $12.24 \%$ & $19.39 \%$ & $7.15 \%$ & $\begin{array}{c}1.888 \\
(0.17)\end{array}$ \\
\hline Special cash distributions ( $\$$ million $)$ & 5.90 & 55.40 & 49.50 & $\begin{array}{c}2.039 \\
(0.04)\end{array}$ \\
\hline Cash distribution as $\%$ of precontest assets & $0.24 \%$ & $1.75 \%$ & $1.51 \%$ & $\begin{array}{c}2.527 \\
(0.01)\end{array}$ \\
\hline Cash/assets & $12.82 \%$ & $9.15 \%$ & $-3.67 \%$ & $\begin{array}{c}-2.344 \\
(0.02)\end{array}$ \\
\hline Excess cash & 0.0722 & 0.0351 & -0.0346 & $\begin{array}{c}-3.086 \\
(0.01)\end{array}$ \\
\hline Market/book ratio & 1.482 & 1.550 & 0.062 & $\begin{array}{c}2.011 \\
(0.05)\end{array}$ \\
\hline Capital expenditure & $5.27 \%$ & $4.84 \%$ & $-0.53 \%$ & $\begin{array}{c}-0.874 \\
(0.39)\end{array}$ \\
\hline Experiencing executive turnover (\%) & $9.18 \%$ & $22.45 \%$ & $13.27 \%$ & $\begin{array}{c}6.649 \\
(0.01)\end{array}$ \\
\hline Sample size & 98 & 98 & 98 & 98 \\
\hline
\end{tabular}

is consistent with this reasoning. Average market/book ratio during the precontest year is 1.48 . It increases to 1.55 in the year following the contest. The difference is statistically significant at the $5 \%$ level, suggesting that the reduction of excessive liquidity is done in a wealth-enhancing manner. The evidence on capital expenditures further corroborates this. In the pre-contest period, the sample firms spent an average of $5.27 \%$ of their net assets on new capital expenditures. This percentage falls to $4.84 \%$ in the post-contest year. Although the difference is not statistically significant at the usual levels, it shows that contest firms at least do not increase their investment activities.

Table IV further reveals a significant increase in the incidence of forced executive turnover among the contest firms in the year after the proxy contest. A forced turnover is defined as the resignation or termination of any of the chairman of the board, the chief executive officer, or the president/chief operating officer. Normal turnover (such as retirement at or above age 65) is excluded, 
although including it does not change the qualitative conclusions. During the 1 year preceding the proxy fight, $9.18 \%$ of the sample firms experienced an executive turnover. This percentage increases to $22.45 \%$ in the year after the contest. The likelihood ratio $\chi^{2}$-test indicates that the increase is significant at the $1 \%$ level.

This result is consistent with prior work. Mulherin and Poulsen (1998) report a $60.39 \%$ executive turnover in the 3 years following a proxy contest not accompanied by a takeover bid. If it is assumed that turnovers are evenly spaced in the 3 years following a contest, this corresponds to an annual turnover rate of $20.13 \%$, which is similar to the finding in this study. It should be noted that the occurrence of executive turnover does not depend on dissidents attaining control of the firm. Dissidents were successful in attaining control of only $27.27 \%$ of the firms that experience an executive turnover in the post-contest period. The contest was settled in $54.55 \%$ of these firms, with some dissident representatives typically co-opted onto the board. Dissidents lost the proxy fight in the remaining $18.18 \%$ of firms with forced executive turnover.

Results presented in Table IV show that the proxy fight is effective in stimulating efficient reduction of corporate liquidity. However, these results hold without regard to the level of pre-contest cash holdings. I investigate whether the level of pre-contest excess cash influences post-contest changes by comparing post-contest changes for firms with positive (69 firms) and negative (29 firms) pre-contest excess cash. Results are presented in Table V. As expected, the reduction in excess cash and raw cash/assets is significantly greater for firms with positive pre-contest excess cash. However, there are no significant differences in average cash distributions across the two subsamples, and the proportion of firms making special cash distributions is higher for negative pre-contest excess cash firms.

This seemingly inconsistent result is due primarily to the effect of one firm in the negative pre-contest excess cash group. In the post-contest year, this firm spent $\$ 983.74$ million (representing $5.37 \%$ of pre-contest assets) on repurchases financed with debt and asset sales. Without this firm, average special cash distribution for firms with negative pre-contest excess cash is only $\$ 1.57$ million, which is significantly lower than the amount spent by firms with positive precontest excess cash ( $p$-value $=0.06$ ).

Excluding this firm, average cash distribution represents $1.77 \%$ of pre-contest assets for negative excess cash firms, compared to $1.69 \%$ for firms with positive pre-contest excess cash. I obtain similar results when I eliminate the largest and smallest spending firm in each group. Although the difference is not significant, this seems to suggest that negative excess cash firms distributed more cash as a proportion of pre-contest assets than did positive excess cash firms in the post-contest year. However, when I consider only firms that actually distributed cash, the results are in the expected direction. Average and median cash distribution as a percentage of pre-contest assets for the eight repurchasing negative excess cash firms are $6.87 \%$ and $5.76 \%$, respectively, compared to $10.61 \%$ and $6.01 \%$ for the 11 repurchasing positive excess cash firms. The differences are not statistically significant due to very small sample sizes. 


\section{Table V}

\section{Precontest Excess Cash Holdings and Postcontest Changes}

Special cash distributions include all forms of stock repurchases (excluding targeted repurchases) and one-time special dividends announced and completed during the period. Capital expenditure is the ratio of capital expenditure to net assets. Excess cash is the prediction error of Opler et al.'s (1999) cash model. Executive turnover includes all resignations or terminations of any of the chairman of the board, the chief executive officer, or the president/chief operating officer, but excludes unforced turnovers such as retirement at normal age. Figures for executive turnover and special cash distributions are based on summaries of news items reported in the Wall Street Journal, Dow Jones News Service, Dow Jones Business News, PR Newswire, and Business Newswire. Figures for market/book ratio and capital expenditure are from COMPUSTAT. All figures apart from proportions are arithmetic averages. The sample covers 1988-2000.

\begin{tabular}{|c|c|c|c|}
\hline & $\begin{array}{l}\text { Positive Excess } \\
\text { Cash ( } 69 \text { Firms) }\end{array}$ & $\begin{array}{l}\text { Negative Excess } \\
\text { Cash (29 Firms) }\end{array}$ & $\begin{array}{c}\text { Test Statistic } \\
(p \text {-value })\end{array}$ \\
\hline Making special cash distributions (\%) & $15.94 \%$ & $27.58 \%$ & $\begin{array}{c}1.77 \\
(0.18)\end{array}$ \\
\hline Special cash distributions ( $\$$ million) & 63.80 & 35.43 & $\begin{array}{c}0.60 \\
(0.55)\end{array}$ \\
\hline Cash distribution as $\%$ of precontest assets & $1.69 \%$ & $1.89 \%$ & $\begin{array}{c}-0.18 \\
(0.86)\end{array}$ \\
\hline Change in cash ratio & $-6.39 \%$ & $2.77 \%$ & $\begin{array}{c}-2.73 \\
(0.01)\end{array}$ \\
\hline Change in excess cash & $-6.04 \%$ & $2.82 \%$ & $\begin{array}{r}-5.30 \\
(0.00)\end{array}$ \\
\hline Change in market/book ratio & 0.064 & 0.059 & $\begin{array}{c}0.08 \\
(0.94)\end{array}$ \\
\hline Change in capital expenditure & $-0.275 \%$ & $-1.24 \%$ & $\begin{array}{c}0.93 \\
(0.36)\end{array}$ \\
\hline Experiencing executive turnover $(\%)$ & $21.74 \%$ & $24.14 \%$ & $\begin{array}{c}0.07 \\
(0.80)\end{array}$ \\
\hline Sample size & 69 & 29 & 98 \\
\hline
\end{tabular}

The higher proportion of negative excess cash firms making special distributions reflects several small buybacks. Half of these firms spent less than $\$ 5$ million on repurchases. In contrast, only one of the 11 repurchasing positive excess cash firms spent less than $\$ 5$ million. Furthermore, cash distributions represent less than $2 \%$ of pre-contest assets for $37.50 \%$ of repurchasing negative excess cash firms, compared to only $18.18 \%$ of repurchasing positive excess cash firms. At the upper end of the distribution, $27.27 \%$ of firms with positive pre-contest excess cash distributed $15 \%$ or more of their pre-contest assets to shareholders following the proxy contest, compared to $12.50 \%$ of firms with negative pre-contest excess cash. Thus, while the results in Table V suggest that negative pre-contest excess cash firms distribute more cash than positive excess cash firms, the results are affected by an outlier. In addition, the results are attenuated by the fact that these firms tend to make smaller distributions than the positive excess cash firms.

An alternative possibility is that management will more readily distribute cash when faced with a proxy fight if dissidents are more specific in their 


\section{Table VI}

\section{Dissidents' Reasons for Launching Contest and Postcontest Changes}

Special cash distributions include all forms of stock repurchases (excluding targeted repurchases) and one-time special dividends announced and completed during the period. Capital expenditure is the ratio of capital expenditure to net assets. Excess cash is the prediction error of Opler et al.'s (1999) cash model. Executive turnover includes all resignations or terminations of any of the chairman of the board, the chief executive officer, or the president/chief operating officer, but excludes unforced turnovers such as retirement at normal age. Figures for executive turnover and special cash distributions are based on summaries of news items reported in the Wall Street Journal, Dow Jones News Service, Dow Jones Business News, PR Newswire, and Business Newswire. Figures for market/book ratio and capital expenditure are from COMPUSTAT. All figures apart from proportions are arithmetic averages. The sample consists of 98 firms involved in proxy fights conducted independently of a takeover bid between 1988 and 2000. In 14 of these contests, dissidents explicitly mentioned cash issues as part of the reasons for launching a contest. Dissidents did not mention cash issues in the remaining 84 contests.

\begin{tabular}{lccc}
\hline & $\begin{array}{c}\text { Cash Issues } \\
\text { Raised by } \\
\text { Dissidents }\end{array}$ & $\begin{array}{c}\text { Cash Issues } \\
\text { Not Raised by } \\
\text { Dissidents }\end{array}$ & $\begin{array}{c}\text { Test Statistic } \\
(p \text {-value) }\end{array}$ \\
\hline Making special cash distributions $(\%)$ & $57.14 \%$ & $13.01 \%$ & $\begin{array}{c}12.054 \\
(0.00)\end{array}$ \\
Special cash distributions $(\$$ million) & 320.64 & 11.20 & $\begin{array}{c}(0.00) \\
2.65\end{array}$ \\
Cash distribution as $\%$ of precontest assets & $5.43 \%$ & $1.14 \%$ & $(0.01)$ \\
Change in cash ratio & $-4.71 \%$ & $-3.50 \%$ & -0.45 \\
Change in excess cash & $-4.17 \%$ & $-3.33 \%$ & $-0.68)$ \\
Change in market/book ratio & 0.123 & 0.052 & $(0.72)$ \\
Change in capital expenditure & & & 0.80 \\
$(0.43)$ & 0.82 \\
Experiencing executive turnover $(\%)$ & $0.72 \%$ & $-0.80 \%$ & $(0.43)$ \\
& & & 2.699 \\
Sample size & $7.14 \%$ & $25.00 \%$ & $(0.10)$ \\
\hline
\end{tabular}

demands. I examine this possibility by comparing post-contest changes for the 14 firms where dissidents explicitly mentioned cash issues as part of their reasons for launching a proxy fight with those for the remaining 84 firms. Twelve of the 14 firms have positive excess cash in the pre-contest year. Consistent with the foregoing, Table VI reveals a sharp contrast between the two subsamples. More than half of the firms with cash issues made a special cash distribution in the year following the proxy fight, compared to just $13.10 \%$ of the other firms. The difference is significant at less than the $1 \%$ level. Similarly, average special cash distribution in dollar terms ( $\$ 320.64$ vs. $\$ 11.20$ million) and as a percentage of pre-contest assets (5.43\% compared to $1.14 \%)$ is significantly higher for the 14 firms.

A surprise finding in Table VI is the lower incidence of executive turnover among the firms in which dissidents mentioned cash issues. Thus, it appears 
that investors are willing to let the same managers continue running these firms. Although it is not clear why this is so, it is possible that investors are satisfied by the changes and believe incumbent management will continue to perform well. The change in market/book ratios provides some support for this conjecture. Average market/book ratio increases by 0.123 for the 14 firms, compared to an increase of only 0.052 for the other firms. However, the difference is not statistically significant at conventional levels, probably because of a lack of statistical power arising from small sample sizes.

\section{Summary and Conclusions}

Recent work documents that the takeover market does not discipline excessively liquid firms. Since excess liquidity is the source of important agency problems discussed by Jensen (1986), these papers raise the question of which control mechanism redirects management toward efficient utilization of cash. I focus on the special characteristics of corporate liquidity that may discourage a bidder from going after cash-rich targets and suggest the proxy contest as an effective alternative. I find that proxy fight targets hold $23 \%$ more cash than comparable non-targets and that the probability of a contest is significantly increasing in excess cash holdings. Furthermore, cash holdings significantly decline following a proxy fight. This is not due to a secular reduction in corporate liquidity or wastage. Instead, target firms significantly increase cash distributions to shareholders. These results confirm the important roles attributed to the proxy contest in agency theory and suggest that managerial or political actions that diminish its effectiveness may be inefficient.

My results also raise important questions for future research. Of particular concern is the relative scarcity of the proxy fight as a corporate control tool. My sample consists of 98 contests over a 13-year period. DeAngelo's (1988) sample is 86 proxy fights over 16 years. Meanwhile, this study and others cited herein indicate that the proxy fight appears to be effective in dealing with agency issues. If the proxy fight is so effective in addressing agency issues, why are there so few of them? What makes some firms more susceptible, and how do shareholders decide who is vulnerable? It is hoped that future research will provide an insight into these issues and enhance our understanding of why many firms are able to avoid a contest.

\section{REFERENCES}

Bagwell, Laurie S., 1991, Share repurchase and takeover deterrence, Rand Journal of Economics $22,72-88$.

Bagwell, Laurie S., 1992, Dutch auction repurchases: An analysis of shareholder heterogeneity, Journal of Finance 47, 71-105.

Copeland, Thomas E., and Won H. Lee, 1991, Exchange offers and stock swaps-New evidence, Financial Management 20, 34-48.

Dann, Larry Y., and Harry DeAngelo, 1988, Corporate financial policy and corporate control: A study of defensive adjustments in asset and ownership structure, Journal of Financial Economics 20, 87-128. 
DeAngelo, Linda E., 1988, Managerial compensation, information costs, and corporate governance: The use of accounting performance measures in proxy contests, Journal of Accounting \& Economics 10, 3-36.

Denis, David J., 1990, Defensive changes in corporate payout policy: Share repurchases and special dividends, Journal of Finance 45, 1433-1456.

Harford, Jarrad, 1999, Corporate cash reserves and acquisitions, Journal of Finance 54, 1969-1997.

Harris, Milton, and Artur Raviv, 1988, Corporate control contests and capital structure, Journal of Financial Economics 20, 55-86.

Jensen, Michael C., 1986, The agency cost of free cash flow, corporate finance, and takeovers, American Economic Review 76, 323-329.

Jensen, Michael C., 1993, The modern industrial revolution, exit, and the failure of internal control systems, Journal of Finance 48, 831-880.

Jensen, Michael C., and William H. Meckling, 1976, Theory of the firm: Managerial behavior, agency costs and ownership structure, Journal of Financial Economics 3, 305-360.

Lehn, Kenneth, and Annette Poulsen, 1989, Free cash flow and stockholder gains in going private transactions, Journal of Finance 44, 771-787.

Masulis, Ronald W., 1980, The effects of capital structure change on security prices: A study of exchange offers, Journal of Financial Economics 8, 139-178.

Mulherin, J. Harold, and Annette Poulsen, 1998, Proxy contests and corporate change: Implications for shareholder wealth, Journal of Financial Economics 47, 279-313.

Nohel, Tom, and Vefa Tarhan, 1998, Share repurchases and firm performance: New evidence on the agency costs of free cash flow, Journal of Financial Economics 49, 187-222.

Opler, Tim, Lee Pinkowitz, René Stulz, and Rohan Williamson, 1999, The determinants and implications of corporate cash holdings, Journal of Financial Economics 52, 3-46.

Opler, Tim, and Sheridan Titman, 1993, The determinants of leveraged buyout activity: Free cash flow vs. financial distress costs, Journal of Finance 48, 1985-1999.

Pinkowitz, Lee, 2002, The market for corporate control and corporate cash holdings, Working paper, Georgetown University.

Pinkowitz, Lee, and Rohan Williamson, 2001, Bank power and cash holdings: Evidence from Japan, Review of Financial Studies 14, 1059-1082.

Pound, John, 1988, Proxy contests and the efficiency of shareholder oversight, Journal of Financial Economics 20, 237-265.

Smith, Clifford W., and Ross L. Watts, 1992, The investment opportunity set and corporate financing, dividend, and compensation policies, Journal of Financial Economics 32, 263-292.

Stephens, Clifford, and Michael Weisbach, 1998, Actual share reacquisitions in open-market repurchase programs, Journal of Finance 53, 313-333.

Stulz, René M., 1988, Managerial control of voting rights: Financing policies and the market for corporate control, Journal of Financial Economics 20, 25-54.

Vermaelen, Theo, 1981, Common stock repurchases and market signaling: An empirical study, Journal of Financial Economics 9, 139-183. 